\title{
METODOLOGIA OCENY RYZYKA POWODZIOWEGO GMIN WOJEWÓDZTWA ŁÓDZKIEGO
}

\author{
Marta Borowska-Stefańska
}

\section{Flood risk assessment methods in municipalities of the Łódź province}

Abstract: The aim of the article is to analyze methods of flood risk assessment used in Poland and to compare the results obtained on the basis of these analyses. The analysis involves 21 communes (Polish: gmina), which in the document created by the Department of Security and Crisis Management of the Łódź Municipal Government were referred to as those in which the damage connected with flooding is the biggest. In accordance with the Flood Directive (2007), flood risk is a "combination of the probability of a flood event and potential adverse consequences for human health, the natural environment, and cultural and economic activity" (Flood Directive of 2007, Art. 2 Item 2). The article uses the methodology implemented in the Flood Control Operating Plan for the Łódź province (2013), Plans of Flood Risk Management (2015), and their results were compared with the author's interpretation. Research has shown that the biggest discrepancies concerning flood risk levels concern five communes: Uniejów, Działoszyn, Warta, Gidle and Sulejów. This is linked with a different attitude towards flood risk. Regrettably, there still exists no reliable method of risk assessment, which would greatly facilitate the pursuance of an adequate anti-flood policy.

Keywords: flood risk, GIS, areas exposed to floods, Flood Directive, Łódź province

Zarys treści: Celem artykułu jest krytyczna ocena wykorzystywanych w Polsce metod oceny ryzyka powodziowego i porównanie wyników uzyskanych na ich podstawie. Analiza dotyczyła 21 gmin, które w dokumencie stworzonym w Wydziale Bezpieczeństwa i Zarządzania Kryzysowego Urzędu Wojewódzkiego w Łodzi zostały wskazane jako te, w których szkody związane z powodziami są najwyższe. Zgodnie z Dyrektywą Powodziową (2007) ryzyko 
powodziowe oznacza „kombinację prawdopodobieństwa wystąpienia powodzi i związanych z nią potencjalnych negatywnych konsekwencji dla zdrowia ludzkiego, środowiska, dziedzictwa kulturowego oraz działalności gospodarczej” (Dyrektywa Powodziowa 2007, art. 2 pkt 2). W artykule wykorzystano metodologię zastosowaną w Planie operacyjnym ochrony przed powodzią dla województwa łódzkiego (2013), planach zarządzania ryzykiem powodziowym (2015), a ich wyniki zestawiono z propozycją autorską. Stwierdzono, że największe rozbieżności w zakresie poziomu ryzyka powodziowego dotyczą pięciu gmin: Uniejowa, Działoszyna, Warty, Gidli oraz Sulejowa. Jest to związane z odmiennym podejściem do zagadnień ryzyka powodziowego. Niestety wciąż brakuje niezawodnej metody jego oceny, co znacząco ułatwiłoby prowadzenie odpowiedniej polityki w zakresie ochrony przeciwpowodziowej.

Stowa kluczowe: ryzyko powodziowe, GIS, tereny zagrożone powodziami, Dyrektywa Powodziowa, województwo łódzkie

\section{Wstęp}

Celem głównym badań jest analiza wykorzystywanych w Polsce metod oceny ryzyka powodziowego i porównanie wyników uzyskanych na ich podstawie, na przykładzie 21 gmin, które w Planie operacyjnym ochrony przed powodzią dla województwa łódzkiego (2013) zostały wskazane jako te, w których szkody związane z powodziami są najwyższe. Do jego realizacji wyznaczono cel szczegółowy, którym była analiza zróżnicowania wybranych gmin województwa łódzkiego według poziomu ryzyka powodziowego.

Powodzie na całym świecie są przyczyną ogromnych szkód, zwłaszcza gdy występują na obszarach gęsto zaludnionych i intensywnie zagospodarowanych. Ogromne środki finansowe przekazywane są na rzecz zapobiegania skutkom powodzi. Decyzje dotyczące wykorzystywanych środków ochrony przed powodzią są podejmowane w wyniku szacowania kosztów oraz korzyści wynikających z tych działań. $Z$ gospodarczego punktu widzenia poniesione nakłady na zabezpieczenia nie powinny przewyższać oczekiwanych efektów. Dlatego też w procesie zarządzania ryzykiem powodziowym tak ważne jest odpowiednie szacowanie szkód (Kang i in. 2005).

Ryzyko powodziowe jest najczęściej definiowane jako iloczyn zagrożenia (fizycznych i statystycznych cech powodzi), ekspozycji (kto i co jest zagrożone przez powódź) oraz wrażliwości (podatności elementów zagospodarowania na zagrożenie i zdolności do przeciwdziałania oraz likwidacji skutków katastrofy) (Merz, Thieken 2004). Współdziałanie tych trzech elementów tworzy tzw. trójkąt ryzyka (Crichton 1999, 2007). Charakter, rodzaj oraz wartość istniejącego stanu zagospodarowania na terenach zagrożonych powodziami decydują o wielkości szkód, które mogą wystąpić w postaci uszkodzeń lub zniszczeń obiektów w wyniku zalania (Chojnacki 2000). Definicja ryzyka powodziowego istniejąca w literaturze została przyjęta w Dyrektywie Powodziowej, gdzie pojęcie to oznacza „kombinację prawdopodobieństwa 
wystąpienia powodzi i związanych z nią potencjalnych negatywnych konsekwencji dla zdrowia ludzkiego, środowiska, dziedzictwa kulturowego oraz działalności gospodarczej" (Dyrektywa Powodziowa 2007, art. 2 pkt 2).

Na obszarach miejskich powodzie wywołują zazwyczaj ogromne szkody, które wynikają m.in. z następujących czynników: lokalizacji budynków oraz infrastruktury miejskiej na terenie zalewowym, ujmowania rzek w kanały (Wołoszyn 2006) oraz przekonania o niezawodności urządzeń hydrotechnicznych (Bogdańska-Warmuz i in. 2000), uszczelniania powierzchni terenu, wskutek czego dochodzi do zmniejszenia lub całkowitego wyeliminowania infiltracji (Wołoszyn 2006). Szkody powodziowe odnoszą się do szerokiego spektrum oddziaływania powodzi na: ludzi, ich zdrowie oraz mienie, infrastrukturę komunalną, dziedzictwo kulturowe, systemy ekologiczne, produkcję przemysłową, konkurencyjność podmiotów gospodarczych dotkniętych powodzią. Dzielimy je, w zależności od sposobu uwzględniania, na: materialne - wyrażane w jednostkach monetarnych, i niematerialne - wyrażane w jednostkach naturalnych. Ponadto ze względu na sposób oddziaływania szkody powodziowe dzielimy na: bezpośrednie - które wynikają z bezpośredniego oddziaływania powodzi na ludzi i ich mienie oraz środowisko, i pośrednie - które są wynikiem długoterminowych konsekwencji powodzi (Sowiński 2008). To właśnie bezpośrednie straty materialne stanowią znaczną część szkód powodziowych (Głosińska 2013), dlatego też największa część literatury odnosi się do ich szacowania (Merz, Thieken 2004). Do czynników, które decydują o wysokości potencjalnych strat powodziowych, zaliczamy: cechy powodzi, użytkowanie terenu, wartość nieruchomości i mienia oraz ich wrażliwość na powódź, która wyrażona jest za pomocą funkcji strat (Głosińska 2013). W modelach strat powodziowych na ogół jednak przyjmuje się jedynie głębokość zalewu. Funkcje uszkodzenia dla budynków są opracowywane zwykle na podstawie danych zgromadzonych po powodziach (Thieken i in. 2005). Wyróżniamy funkcje strat: względnych, które przedstawiają udział zniszczeń w całkowitej wartości strat w zależności od głębokości powodzi, oraz absolutnych, które przedstawiają bezwzględne wartości strat dla każdego obiektu (Głosińska 2013).

W Polsce w ramach projektu „Informatyczny system osłony kraju przed nadzwyczajnymi zagrożeniami" (ISOK) dokonano wstępnej oceny ryzyka powodziowego oraz opracowano mapy zagrożenia i mapy ryzyka powodziowego, stworzono również plany zarządzania ryzykiem powodziowym. Mapy te wykonano na podstawie wytycznych zawartych w Rozporządzeniu Ministra Środowiska, Ministra Transportu, Budownictwa i Gospodarki Morskiej, Ministra Administracji i Cyfryzacji oraz Ministra Spraw Wewnętrznych z dnia 21 grudnia 2012 r. w sprawie opracowywania map zagrożenia powodziowego oraz map ryzyka powodziowego, i opublikowano w Hydroportalu ISOK pod koniec 2013 r. Dokumenty te zostały sporządzone zgodnie z postanowieniami Dyrektywy Powodziowej, której zapisy Polska zobo- 
wiązała się wdrożyć do systemu prawnego (http://www.kzgw.gov.pl/Dyrektywa-Powodziowa.html, 27.11.2013). Głównym celem Dyrektywy Powodziowej jest ograniczanie ryzyka powodziowego oraz zmniejszanie następstw powodzi, właściwe zarządzanie ryzykiem, jakie może stwarzać powódź dla zdrowia ludzkiego, środowiska, działalności gospodarczej i dziedzictwa kulturowego oraz przygotowanie obywateli do radzenia sobie w sytuacji wystąpienia powodzi (Rotnicka 2011). Jest to jedyny dokument, który stanowi wyraźne odniesienie do oceny ryzyka powodziowego w Polsce.

Mapy zagrożenia oraz mapy ryzyka powodziowego to dokumenty, które powstały po to, by poznać intensywność zjawiska powodzi, a następnie poziom ryzyka powodziowego, jakie za sobą niesie na konkretnym obszarze. Na mapach zagrożenia powodziowego przedstawiono:

1. Obszary, na których prawdopodobieństwo wystąpienia powodzi jest niskie i wynosi raz na 500 lat, lub takie, na których występuje prawdopodobieństwo pojawienia się zdarzenia ekstremalnego.

2. Obszary szczególnego zagrożenia powodzią (wcześniej definiowane jako obszary bezpośredniego zagrożenia powodzią).

3. Obszary obejmujące tereny narażone na zalanie w przypadku:

- przelania się wód przez koronę wału przeciwpowodziowego;

- zniszczenia lub uszkodzenia wału przeciwpowodziowego;

- zniszczenia lub uszkodzenia budowli piętrzących;

- zniszczenia lub uszkodzenia budowli ochronnych pasa technicznego.

Dla omawianych obszarów na mapach zagrożenia powodziowego zaprezentowano:

- zasięg powodzi;

- głębokość wody lub poziom zwierciadła wody;

- prędkość przepływu wody lub natężenie przepływu wody - w uzasadnionych przypadkach (Ustawa z dnia 18 lipca 2001 r. Prawo wodne ... 2001).

Omawiane mapy przygotowano w dwóch zestawach tematycznych:

- mapę zagrożenia powodziowego wraz z głębokością wody;

- mapę zagrożenia powodziowego wraz z prędkościami oraz kierunkami przepływu wody.

Rozporządzenie w sprawie opracowywania map zagrożenia i map ryzyka powodziowego z 2012 r. określa dokładnie warunki głębokości wody, które musiały zostać uwzględnione:

- poniżej 0,5 m - wskazująca na niskie zagrożenie dla ludzi i obiektów budowlanych;

- od 0,5 m do $2 \mathrm{~m}$ - wskazująca na średnie zagrożenie dla ludzi, ale wysokie ze względu na straty materialne;

- od 2 m do 4 m - wskazująca na wysokie zagrożenie dla ludzi; 
- powyżej 4 m - wskazująca na bardzo wysokie zagrożenie dla ludzi i ekstremalnie wysokie zagrożenie wystąpienia szkód całkowitych.

Przedziały głębokości określono ze względu na zagrożenie ludzi i potrzeby ewentualnego opracowania planów ewakuacyjnych. Kryteria, które zostały wyznaczone dla map zagrożenia powodziowego, są powszechnie używane w krajach UE: Holandii, Francji, Niemczech oraz Szwajcarii (Kurczyński 2012).

Mapy ryzyka powodziowego sporządzono dla obszarów zagrożonych powodziami (Ustawa Prawo wodne, art. 88d ust. 2). Przedstawiają one potencjalne negatywne skutki związane z powodzią. Zostały przygotowane (na koniec grudnia 2013 r.) w podziale na dwa zestawy tematyczne:

- mapy ryzyka powodziowego przedstawiające zagrożenie dla ludności oraz potencjalne straty powodziowe;

- mapy ryzyka powodziowego przedstawiające użytkowanie terenu oraz obszary i obiekty o szczególnym znaczeniu kulturowym, przyrodniczym, gospodarczym. Ryzyko powodziowe wyrażono poprzez określenie zmiennych społeczno-ekonomicznych, tj.:

- szacunkową liczbę mieszkańców potencjalnie dotkniętych powodzią, określaną na podstawie liczby osób zameldowanych;

- budynki mieszkalne;

- wartości potencjalnych strat powodziowych;

- obiekty o szczególnym znaczeniu społecznym;

- obszary i obiekty o szczególnym znaczeniu kulturowym, przyrodniczym i gospodarczym;

- klasy użytkowania terenu (Rozporządzenie Ministra Środowiska... 2013). Mapy ryzyka powodziowego przedstawiają również wartości strat powodziowych wyznaczonych dla ośmiu klas użytkowania terenu:

- terenów zabudowy mieszkaniowej;

- terenów przemysłowych;

- komunikacji;

- lasów;

- terenów rekreacyjno-wypoczynkowych;

- użytków rolnych;

- wód;

- pozostałych.

Ponadto na omawianych mapach znajdują się budynki mieszkalne oraz o znaczeniu społecznym, dla których określono średnie głębokości wody. Dzięki temu można oszacować stopień zagrożenia ludności według następujących klas:

- głębokość wody < 2 m (niskie i średnie zagrożenie dla ludzi);

- głębokość wody > 2 m (wysokie i bardzo wysokie zagrożenie dla ludzi). 
Rozporządzenie w sprawie opracowywania map zagrożenia i map ryzyka powodziowego z 2012 r. jasno określa sposób obliczania wartości potencjalnych strat powodziowych, w poszczególnych klasach użytkowania terenu. Podstawą do ich szacowania była metodyka stosowana w Niemczech. Wykorzystano w niej funkcję strat, która zależy od głębokości wody oraz rodzaju użytkowania terenu.

Mapy ryzyka powodziowego stanowią niezwykle cenne źródło informacji o stanie zagospodarowania przestrzennego terenów zagrożonych powodziami. Jest to jedyne opracowanie, które w sposób kompleksowy ujmuje tę tematykę. Zawierają one dane o szacunkowych stratach, a także o zagrożonych obiektach w postaci przestrzennej bazy danych GIS. Zabrakło na nich jednak zróżnicowania poziomu tego ryzyka, aby było ono porównywalne między różnymi odcinkami rzek.

Informacje te zostały natomiast zawarte $\mathrm{w}$ planach zarządzania ryzykiem powodziowym. Zostały one przygotowane dla dwóch poziomów odniesienia - obszarów dorzeczy i regionów wodnych. Celem tych dokumentów jest ograniczenie potencjalnych negatywnych skutków powodzi poprzez realizację wybranych działań służących minimalizacji zidentyfikowanych zagrożeń (http://www.powodz.gov.pl/ pl/plany, 7.07.2015). Podstawą ich opracowania były mapy zagrożenia i mapy ryzyka powodziowego. W wyniku ich analizy określono poziom ryzyka z wykorzystaniem metody średniej straty rocznej dla trzech jednostek: heksagonów o powierzchni 0 ha, obszarów gmin, czterokilometrowych odcinków rzek i wybrzeża. Podstawą do określenia poziomu ryzyka powodziowego były wskaźniki związane z potencjalnymi negatywnymi konsekwencjami powodzi, które obliczono z uwzględnieniem stref wody $0,2 \%, 1 \%$ i $10 \%$. W przypadku heksagonów i obszarów gmin poziom ryzyka obliczono niezależnie, w przypadku zaś odcinków rzek i wybrzeża przeniesiono wyniki uzyskane dla heksagonów. W celu oceny zintegrowanego poziomu ryzyka wykorzystano metodę średniej ważonej z uwzględnieniem następujących współczynników wagowych dla poszczególnych kategorii: zdrowie i życie ludzi - 0,54, środowisko - 0,07, dziedzictwo kulturowe - 0,07, działalność gospodarcza - 0,32. Łącznie wyodrębniono pięć poziomów ryzyka: bardzo niski (1), niski (2), umiarkowany (3), wysoki (4), bardzo wysoki (5) (http://www.powodz.gov.pl/pl/plan_view?id=1, 7.07.2015).

Przed ogłoszeniem map zagrożenia i ryzyka powodziowego oraz planów zarządzania ryzykiem powodziowym istniały próby oceny ryzyka powodziowego. Metodykę obliczania strat powodziowych dla terenów zalewowych opisał m.in. Chojnacki (1994). W metodzie tej dla oceny wielkości strat należało określić rodzaj zainwestowania (grunty orne, użytki zielone, wały, brzegi uregulowane, budynki, drogi krajowe, mosty na drogach krajowych, drogi wojewódzkie i gminne, mosty na drogach wojewódzkich i gminnych, szlaki kolejowe, mosty kolejowe). Następnie ze względu na rodzaj zainwestowania ustalono wskaźniki jednostkowych wartości (tys. zł/ha, tys. zł/km, tys. zł/szt.) oraz szacunkową wartość uszkodzeń i na tej pod- 
stawie obliczano wskaźniki strat jednostkowych. Wskaźniki te były zróżnicowane ze względu na położenie, inne obowiązywały dla terenów górskich i podgórskich oraz nizinnych.

Od momentu wejścia w życie Dyrektywy Powodziowej (2007), dyskutowano i przedstawiano metodykę tworzenia map zagrożenia, map ryzyka oraz planów zarządzania ryzykiem powodziowym w różnych krajach (Barszcz i in. 2013; Drożdżal i in. 2009). Metody te nie zostały jednak bezpośrednio wykorzystane do oceny ryzyka powodziowego w województwie łódzkim.

$\mathrm{Na}$ badanym obszarze pierwszą próbę oceny ryzyka powodziowego (jeszcze przed ukazaniem się map zagrożenia i map ryzyka powodziowego) podjął Wydział Bezpieczeństwa i Zarządzania Kryzysowego Urzędu Wojewódzkiego w Łodzi, a jej wyniki stanowią część Planu operacyjnego ochrony przed powodzią dla województwa łódzkiego (2013). Analiza ta opierała się na informacjach przesłanych w 2012 r. z jednostek samorządu terytorialnego, danych będących w posiadaniu Oddziału Zarządzania Kryzysowego Łódzkiego Urzędu Wojewódzkiego w Łodzi, a także funkcjonującego w strukturach tego Oddziału - Wojewódzkiego Centrum Zarządzania Kryzysowego. W zastosowanej metodzie ryzyko powodziowe zostało sklasyfikowane za pomocą pięciu stopni, od minimalnego do bardzo dużego (minimalne, małe, średnie, duże i bardzo duże). Poszczególne stopnie wyliczono za pomocą arkusza kalkulacyjnego, w ramach którego uwzględniono dziewięć różnych czynników, obrazujących sytuację powodziową na obszarze jednostki samorządowej (cieki, częstotliwość występowania powodzi, powierzchnię zalewową w stosunku do wielkości jednostki samorządowej, liczbę mieszkańców na terenach zalewowych, ludność przewidzianą do ewakuacji, rodzaj zabudowy na terenach zalewowych, zbiorniki wodne, drogi na terenach zalewowych, infrastrukturę wrażliwą na terenach zalewowych). W ramach każdego czynnika możliwe było określenie natężenia występowania danego zjawiska: od poziomu marginalnego do istotnego z punktu widzenia bezpieczeństwa powodziowego danego samorządu.

$\mathrm{Na}$ podstawie arkusza określono poziom ryzyka powodziowego danej gminy w formie jednego (wypadkowego) parametru (HG) zgodnie z poniższą zależnością:

$\mathrm{HG}=\sum_{i=I} \frac{n i}{L b i}$

gdzie:

HG - wypadkowy wskaźnik ryzyka powodziowego gminy;

$n i$ - liczba kryteriów (czynników) zagrożenia, które zostały zakwalifikowane do $i$-tego stopnia ryzyka;

$L B i$ - liczba bazowa (waga) dla i-tego stopnia ryzyka (Ocena zagrożenia ... 2012).

Powyższa zależność opierała się na obliczeniu średniej ważonej ze wszystkich czynników ryzyka ujętych w arkuszu kalkulacyjnym. Waga danego czynnika 
Tab. 1. Wartości liczby bazowej dla poszczególnych stopni ryzyka powodziowego

Table 1. Base values for different degrees of flood risk

\begin{tabular}{|c|c|}
\hline $\begin{array}{c}\text { Stopień ryzyka } \\
\text { powodziowego gminy/ } \\
\text { Degree of local flood risk }\end{array}$ & $\begin{array}{c}\text { Wartość liczby } \\
\text { bazowej LB/Base } \\
\text { value } \mathrm{LBi}\end{array}$ \\
\hline ZIG & $\mathrm{L} \mathrm{BI}=5$ \\
\hline ZIIG & $\mathrm{L} \mathrm{BII}=4$ \\
\hline ZIIIG & $\mathrm{LBIII}=3$ \\
\hline ZIVG & $\mathrm{LBIV}=2$ \\
\hline ZVG & $\mathrm{LBV}=1$ \\
\hline
\end{tabular}

Źródto: Ocena zagrożenia powodziowego na obsæarze województwa tódzkiego, 2012.

Source: Assessment of flood risk in the Łód; province, 2012. wzrastała proporcjonalnie w zależności od stopnia, do którego został zakwalifikowany. Wartości liczby bazowej dla poszczególnych stopni ryzyka powodziowego zostały przedstawione w tab. 1.

Po obliczeniu omawianego parametru ustalono stopień ryzyka powodziowego gminy. Dokonano tego poprzez porównanie obliczonej wartości wskaźnika ryzyka z wartościami przedstawionymi w tab. 2.

Wyniki przeprowadzonej analizy wskazały, że na 149 gmin z obszaru województwa łódzkiego w dwóch ryzyko powodziowe jest bardzo duże, a w 19 duże (ryc. 1, tab. 3).

Analiza ta, choć objęła cały obszar województwa łódzkiego (które jest często pomijane w opracowaniach z zakresu powo-

Tab. 2. Stopnie ryzyka powodziowego dla gmin województwa łódzkiego

Table 2. Degree of flood risk for the Łódź province

\begin{tabular}{|c|c|c|}
\hline $\begin{array}{c}\text { Stopień ryzyka powodziowego } \\
\text { gminy/Degree of local flood risk }\end{array}$ & $\begin{array}{c}\text { Przedziały wartości wskaźnika ryzyka powodziowego } \\
\text { gminy HG/Flood risk ratios for municipality HG }\end{array}$ & $\begin{array}{c}\text { Ryzyko powodziowe/ } \\
\text { Flood risk }\end{array}$ \\
\hline ZIG & $1.8-2.03$ & minimum \\
\hline ZIIG & $2.04-2.64$ & low \\
\hline ZIIIG & $2.65-3.76$ & average \\
\hline ZIVG & $3.77-6.77$ & significant \\
\hline ZVG & $6.78-9.0$ & wery high \\
\hline
\end{tabular}

Źródto: Ocena zagrożenia powodziowego na obszarze województwa tódzkiego, 2012.

Source: Assessment of flood risk in the Łódź province, 2012.

dzi ponieważ straty są tu znacznie mniejsze niż w innych regionach, chociażby w południowej Polsce), zawierała pewne błędy oraz - podobnie jak mapy ryzyka - nie uwzględniła zróżnicowania jego poziomu na obszarach zagrożonych. $Z$ uwagi na to, że nie ma jednej skutecznej metody oceny ryzyka powodziowego, autorka postanowiła zaproponować własną metodologię wyznaczania jego poziomu. 


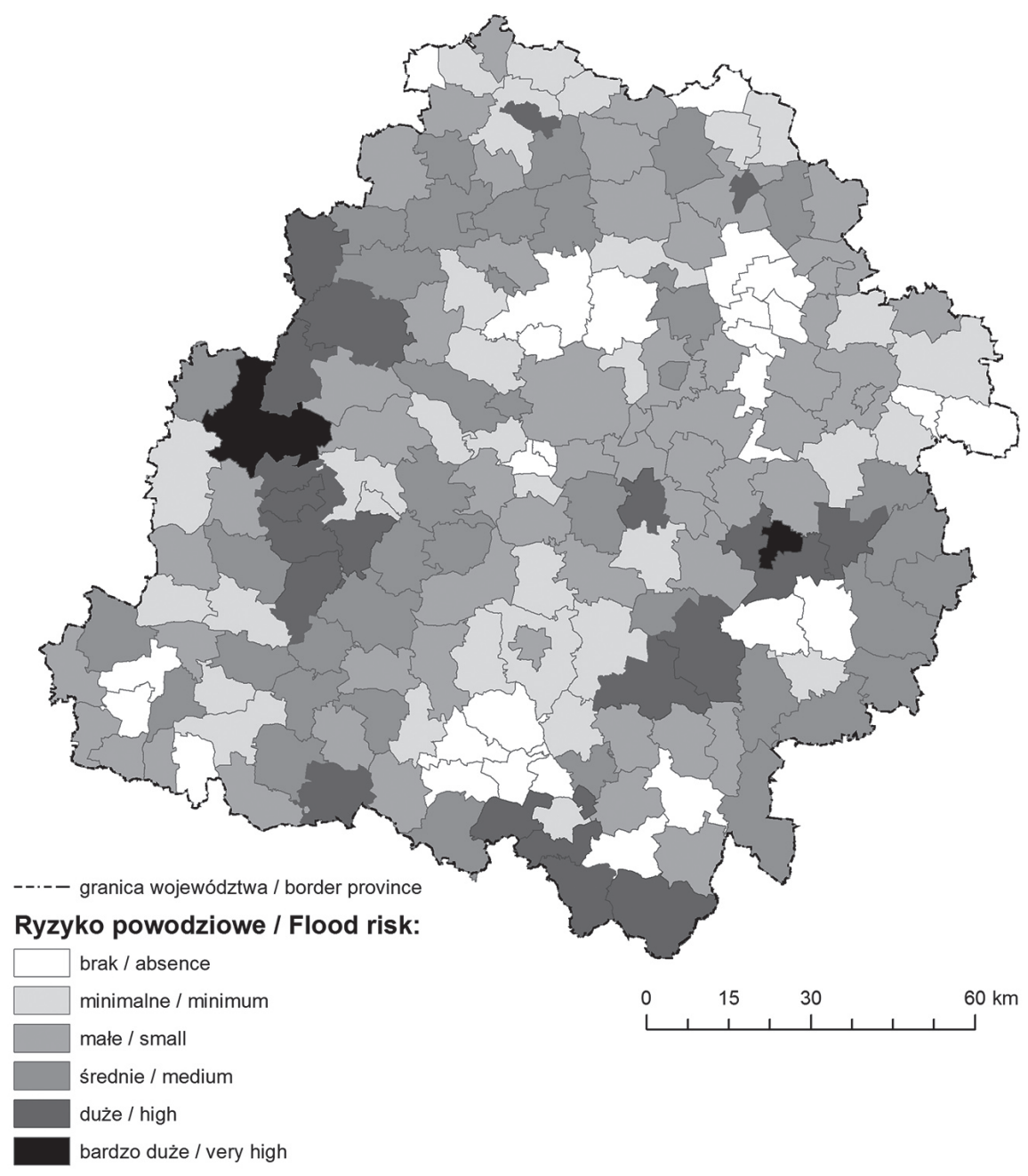

Ryc. 1. Poziom ryzyka powodziowego w gminach województwa łódzkiego według metodologii wykorzystanej w Planie operacyjnym ochrony przed powodzią

Fig. 1. Level of flood risk in the municipalities of Łódź province according to the methodology used in the Operational Flood Protection Plan

Źródto: Plan operacyjny ochrony præed powodziq dla województwa tódzkiego, 2013.

Source: Operational Flood Protection Plan for Łódź province, 2013. 
Tab. 3. Klasyfikacja gmin o najwyższym poziomie ryzyka według metodologii wykorzystanej w Planie operacyjnym ochrony przed powodzią dla województwa łódzkiego

Table 3. Classification of municipalities with the highest level of flood risk according to the methodology used in the Operational Flood Protection Plan for the Łódź province

\begin{tabular}{|r|l|}
\hline \multicolumn{1}{|c|}{ Lp. } & Gmina/Community \\
\hline $\mathbf{1}$ & Tomaszów Mazowiecki (city) \\
\hline $\mathbf{2}$ & Warta \\
\hline $\mathbf{3}$ & Radomsko \\
\hline $\mathbf{4}$ & Sieradz (city) \\
\hline $\mathbf{5}$ & Sulejów \\
\hline $\mathbf{6}$ & Łowicz \\
\hline $\mathbf{7}$ & Poddębice \\
\hline $\mathbf{8}$ & Żytno \\
\hline $\mathbf{9}$ & Kutno \\
\hline $\mathbf{1 0}$ & Pęczniew \\
\hline $\mathbf{1 1}$ & Inowłódz \\
\hline
\end{tabular}

\begin{tabular}{|c|l|}
\hline Lp. & Gmina/Community \\
\hline 12 & Sieradz (rural municipality) \\
\hline 13 & Burzenin \\
\hline 14 & Tomaszów Mazowiecki (rural municipality) \\
\hline 15 & Rozprza \\
\hline 16 & Ładzice \\
\hline 17 & Działoszyn \\
\hline 18 & Gidle \\
\hline 19 & Czarnocin \\
\hline 20 & Uniejów \\
\hline 21 & Zapolice \\
\hline
\end{tabular}

Źródto: Ocena zagro:̇enia powodziowego na obszarze województwa tódzkiego, 2012.

Source: Assessment of flood risk in Łódź province, 2012.

\section{Materiały źródłowe i metodologia}

Ocenę ryzyka powodziowego przeprowadzono w granicach terenów wody 100-letniej, w 21 gminach województwa łódzkiego o dużym i bardzo dużym poziomie ryzyka. Jest to zadanie niezwykle istotne, dzięki niemu możliwe jest racjonalne prowadzenie działań związanych z ochroną przeciwpowodziową (Szypuła 2001). Ocena ryzyka powodziowego związana jest z oceną wielkości szkód wszystkich kategorii dla terenów zagrożonych o różnym prawdopodobieństwie wystąpienia powodzi, a jej efektywność w dużej mierze uzależniona jest od dostępnych danych topograficznych (Nachlik 2011). Na podstawie analizy bieżącego zagospodarowania terenów zagrożonych powodziami w wybranych gminach dokonano identyfikacji obiektów i terenów, generujących ryzyko powodziowe. Ze względu na duże ich zróżnicowanie w granicach wody 100-letniej wydzielono cztery grupy ryzyka powodziowego:

- obiekty społeczne, gdzie na stałe lub czasowo może przebywać duża liczba osób;

- obiekty dziedzictwa kulturowego i tereny cenne przyrodniczo;

- obiekty potencjalnie zagrażające środowisku przyrodniczemu oraz ludziom;

- tereny generujące straty ekonomiczne. 
Grupa 1. W grupie obiektów społecznych znalazły się następujące budynki:

- mieszkaniowe (zarówno jedno-, jak i wielorodzinne);

- szpitale;

- szkoły;

- przedszkola;

- hotele;

- sanatoria.

Grupa 2. Do grupy obszarów wartościowych przyrodniczo oraz dziedzictwa kulturowego zaliczono:

- obszary Natura 2000;

- rezerwaty przyrody;

- parki krajobrazowe;

- ogrody zoologiczne;

- obszary i obiekty zabytków nieruchomych, w szczególności objętych formami ochrony zabytków, o których mowa w art. 7 pkt 1 ustawy z dnia 23 lipca 2003 r. o ochronie zabytków i opiece nad zabytkami (Dz.U. 2003 Nr 162 poz.1568, z późn. zm.);

- zabytki wpisane na Listę dziedzictwa światowego, o której mowa w art. 11 ust. 2 Konwencji w sprawie ochrony światowego dziedzictwa kulturalnego i naturalnego, przyjętej w Paryżu dnia 16 listopada 1972 r. przez Konferencję Generalną Organizacji Narodów Zjednoczonych dla Wychowania, Nauki i Kultury na jej siedemnastej sesji (Dz.U. 1976 Nr 32 poz. 190);

- skanseny i muzea wpisane do Państwowego Rejestru Muzeów, o których mowa w art. 13 ustawy z dnia 21 listopada 1996 r. o muzeach (Dz.U. 2012 poz. 987).

Grupa 3. W grupie obiektów, które potencjalnie mogą zagrażać zarówno ludziom, jak i środowisku przyrodniczemu w przypadku wystąpienia powodzi znalazły się:

- oczyszczalnie ścieków;

- przepompownie;

- składowiska odpadów;

- zakłady przemysłowe, w tym:

- instalacje lub zespoły instalacji, na których prowadzenie jest wymagane uzyskanie pozwolenia zintegrowanego w rozumieniu art. 181 ust.1 pkt 1 Ustawy z dnia 27 kwietnia 2001 r. Prawo ochrony środowiska (Dz.U. 2008 Nr 25 poz. 150 z późn. zm.), w następujących kategoriach działalności przemysłowej:

a) przemysł energetyczny;

b) produkcja i obróbka metali;

c) przemysł mineralny;

d) przemysł chemiczny; 
e) gospodarka odpadami;

f) inne rodzaje działalności, obejmujące:

- produkcję i przetwórstwo papieru oraz drewna;

-intensywny chów lub hodowlę drobiu i świń;

- produkcję i przetwarzanie surowców roślinnych i zwierzęcych;

- zakłady przemysłowe, które nie wymagają pozwolenia, o którym mowa w pkt 1, a które mogą stwarzać zagrożenie, w tym zakłady będące zakładami o dużym ryzyku wystąpienia awarii albo zwiększonym ryzyku wystąpienia awarii, w rozumieniu art. 248 ust. 1 Ustawy z dnia 27 kwietnia 2001 r. Prawo ochrony środowiska.

Grupa 4. Tereny generujące straty ekonomiczne. Wyceny strat materialnych dokonano przy użyciu Bazy Danych Obiektów Topograficznych (BDOT). Zgodnie z Rozporządzeniem Ministra Środowiska, Ministra Transportu, Budownictwa i Gospodarki Morskiej, Ministra Administracji i Cyfryzacji oraz Ministra Spraw Wewnętrznych z dnia 21 grudnia 2012 r. w sprawie opracowywania map zagrożenia powodziowego oraz map ryzyka powodziowego w celu określenia potencjalnych strat majątku na obszarach zagrożonych powodziami, należy wydzielić następujące obszary użytkowania terenu:

- osiedla mieszkaniowe;

- tereny działalności gospodarczych;

- tereny komunikacyjne;

- lasy;

- tereny rekreacyjno-wypoczynkowe;

- użytki rolne;

- wody;

- pozostałe obszary, dla których nie są określane straty powodziowe.

We wszystkich wydzielonych grupach (1-4) ryzyka powodziowego dokonano jego oceny, od poziomu minimalnego (1), do bardzo dużego (5), gdzie polem podstawowym był heksagon o powierzchni 0,5 ha. Tereny zagrożone powodzią podzielono na heksagony w programie Geospatial Modelling Environment. Wielkość heksagonu została dopasowana w taki sposób, by jak najwięcej pełnych figur zmieściło się w granicach analizowanego terenu. Poziom ryzyka określono przy założeniu, że głębokość zalania wyniesie od $0,5 \mathrm{~m}$ do $2 \mathrm{~m}$.

Następnie stworzono mapę, na której znalazła się syntetyczna ocena poziomu ryzyka powodziowego na badanych obszarach, dzięki której możliwe jest odpowiednie zarządzanie ryzykiem (ryc. 2).

W grupie obiektów społecznych, dziedzictwa kulturowego i terenów cennych przyrodniczo, a także obiektów potencjalnie zagrażających środowisku przyrodniczemu oraz ludziom, przy ocenie poziomu ryzyka powodziowego brano pod 


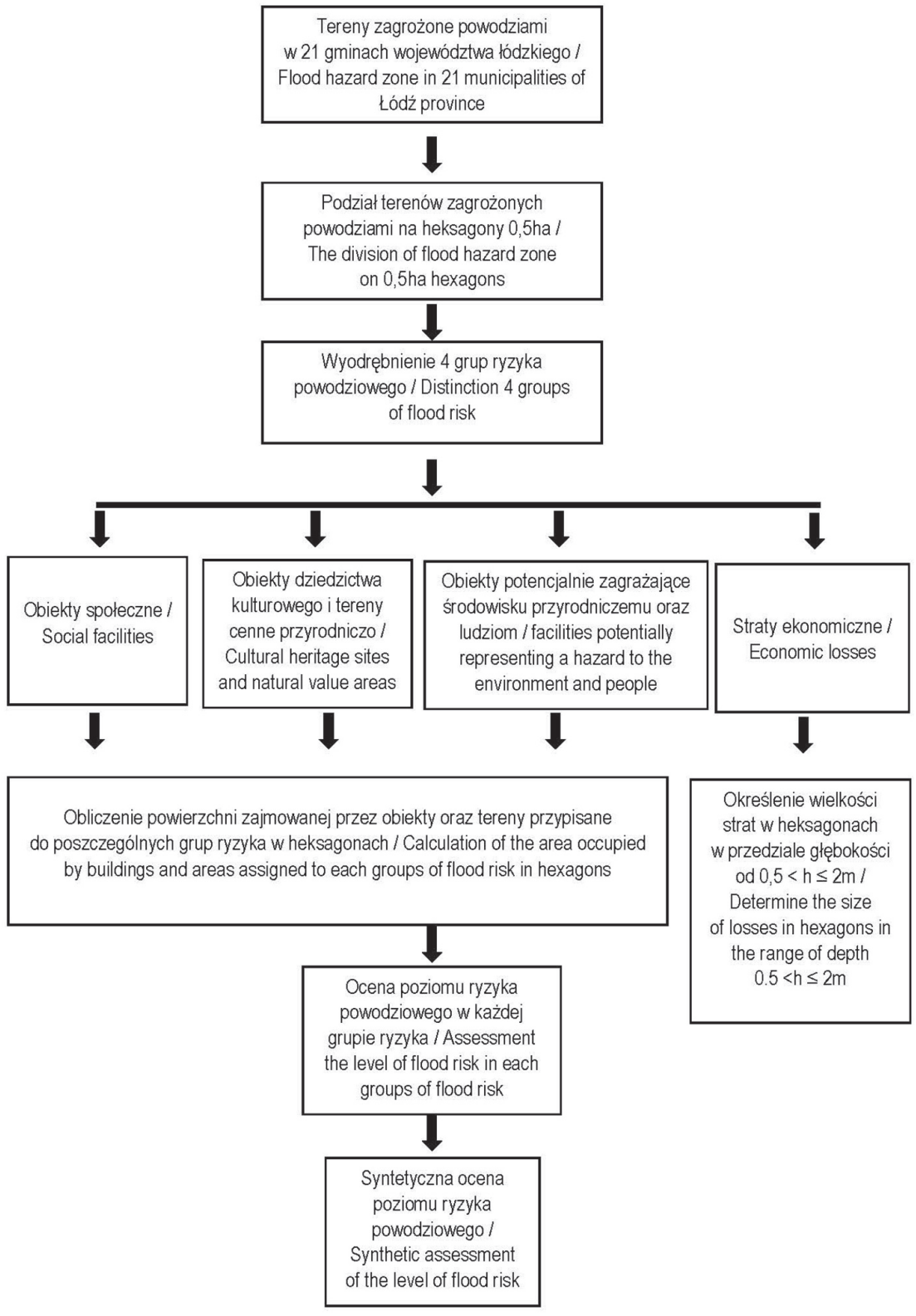

Ryc. 2. Autorska metoda oceny ryzyka powodziowego

Fig. 2. Author's assessment of the level of flood risk

Źródto: opracowanie własne.

Source: author's own work. 
uwagę powierzchnię, jaką zajmują w każdym heksagonie. Obszar heksagonu (0,5 ha) podzielono na pięć równych klas (co 0,1 ha) - im większa powierzchnia w obrębie heksagonu zajęta przez budynki lub tereny przypisane do danej grupy ryzyka powodziowego, tym wyższy jego poziom. Jeśli obiekty lub obszary zajmowały powierzchnię w heksagonie do $1000 \mathrm{~m}^{2}$ (jednak więcej niż 0), otrzymywały poziom ryzyka minimalny (1); od 1001-2000 $\mathrm{m}^{2}$, poziom ryzyka był mały (2), od 2001-3000 $\mathrm{m}^{2}$ - poziom ryzyka średni (3); 3001-4000 $\mathrm{m}^{2}$ - poziom ryzyka duży, $>4000 \mathrm{~m}^{2}$ - poziom ryzyka bardzo duży.

Oceny strat ekonomicznych dokonano, analizując siedem wydzielonych obszarów użytkowania ziemi w każdym heksagonie. Wartość strat jednostkowych dla terenów mieszkaniowych, terenów działalności gospodarczych oraz komunikacyjnych ściśle związana jest z głębokością wody, a tym samym ze stopniem utraty wartości majątku (tab. 4).

Tab. 4. Stopień utraty majątku ze względu na funkcję oraz głębokość wody Table 4. Loss of property due to the destructive impact and depth of water

\begin{tabular}{|l|c|}
\hline \multicolumn{1}{|c|}{$\begin{array}{c}\text { Klasa użytkowania terenu/ } \\
\text { Class of land use }\end{array}$} & $\begin{array}{c}\text { Wartość funkcji strat } \mathrm{f}(\mathrm{h})[\%] \text { w przedziale głębokości od } 0,5<\mathrm{h} \leq 2 \mathrm{~m} / \\
\text { Loss value } \mathrm{f}(\mathrm{h})[\%] \text { for the range of water depths } 0.5<\mathrm{h} \leq 2 \mathrm{~m}\end{array}$ \\
\hline Tereny zabudowy mieszkaniowej & 35 \\
\hline Tereny działalności gospodarczych & 40 \\
\hline Tereny komunikacyjne & 10 \\
\hline
\end{tabular}

Źródto: Rozporządzenie Ministra Środowiska... 2012.

Source: Regulation of the Minister of the Environment... 2012.

Dopiero łącznie trzy elementy: użytkowanie terenu, głębokość wody oraz wartość majątku (która dla terenów mieszkaniowych oraz działalności gospodarczych jest zróżnicowana według województw) służą do szacowania potencjalnych strat liczonych w pieniądzu (tab. 5).

Sposób dokonywania wyceny majątku zaproponowany w Rozporządzeniu (2012) został oparty o metodologię stosowaną w Niemczech (Drożdżal i in. 2009).

Przy ocenie ryzyka związanego z potencjalnymi stratami ekonomicznymi zliczona została powierzchnia zajmowana przez wyodrębnione klasy użytkowania terenu, w każdym heksagonie. Następnie obliczono dla każdej z nich wartość majątku, która została zsumowana w obrębie pola podstawowego (heksagonu). Za maksymalny poziom ryzyka przyjęto wartość strat dla terenów działalności gospodarczych. Maksymalna wielkość strat w heksagonie wynosiła 1658,4 tys. zł. Utworzono pięć równych przedziałów wartości majątku (co 331,68 tys. zł) i dla każdego z nich określono poziom ryzyka - od minimalnego do bardzo dużego - uzyskując obraz 
Tab. 5. Wartość utraty majątku w województwie łódzkim ze względu na klasy użytkowania terenu

Table 5. Value of property loss in the Łódź region versus land use class

\begin{tabular}{|l|c|}
\hline \multicolumn{1}{|c|}{$\begin{array}{c}\text { Klasa użytkowania terenu/ } \\
\text { Class of land use }\end{array}$} & $\begin{array}{c}\text { Wartość funkcji strat } \mathrm{f}(\mathrm{h})[\%] \text { w przedziale głebokości od } 0,5<\mathrm{h} \leq 2 \mathrm{~m} / \\
\text { Loss value } \mathrm{f}(\mathrm{h})[\%] \text { for the range of water depths } 0.5<\mathrm{h} \leq 2 \mathrm{~m}\end{array}$ \\
\hline Tereny zabudowy mieszkaniowej & $101,83 \mathrm{z} / \mathrm{m}^{2}$ \\
\hline Tereny działalności gospodarczych & $331,68 \mathrm{z} \mathrm{z} / \mathrm{m}^{2}$ \\
\hline Tereny komunikacyjne & $43,6 \mathrm{z} / \mathrm{m}^{2}$ \\
\hline Lasy & $80 \mathrm{z} / \mathrm{ha}$ \\
\hline Tereny rekreacyjno-wypoczynkowe & $5,1 \mathrm{z} / \mathrm{m}^{2}$ \\
\hline Grunty orne & $1,428 \mathrm{z} / \mathrm{ha}$ \\
\hline Użytki zielone & $674 \mathrm{z} / \mathrm{ha}$ \\
\hline
\end{tabular}

Źródto: Rozporządzenie Ministra Środowiska... 2012.

Source: Regulation of the Minister of the Environment ... 2012.

wielkości ryzyka powodziowego ze względu na straty ekonomiczne (Borowska-Stefańska 2014, 2015a, b).

W celu zróżnicowania gmin według poziomu ryzyka powodziowego przeanalizowano udział heksagonów o określonym stopniu ryzyka, w granicach wody 100-letniej, w każdej wyodrębnionej grupie. Pod uwagę brano jedynie heksagony o powierzchni powyżej 0,4 ha gdyż tylko w ich granicach możliwe było uzyskanie najwyższego poziomu ryzyka powodziowego. $Z$ dalszej analizy wyeliminowano te heksagony, których powierzchnia była mniejsza. Następnie stworzono ranking gmin, w każdej grupie ryzyka powodziowego, według wzoru:

$P=\frac{\sum U \cdot R_{i-\operatorname{teg} 0}}{5}$

gdzie

$P$ - poziom ryzyka w danej grupie;

$U$ - udział heksagonów o określonym poziomie ryzyka powodziowego w danej grupie, w powierzchni terenu wody 100-letniej danej gminy;

$R_{\text {i-tego }}$ - stopień ryzyka w określonej grupie;

5 - liczba poziomów ryzyka.

W wyniku tych obliczeń uzyskano wartości dla wszystkich gmin, w każdej grupie ryzyka powodziowego, które uszeregowano malejąco zgodnie z uzyskanymi wielkościami, i na tej podstawie stworzono ranking gmin według jego poziomu.

$\mathrm{Na}$ koniec dokonano oceny syntetycznego poziomu ryzyka powodziowego w badanych gminach województwa łódzkiego (tab. 6). W tej klasyfikacji brano pod uwagę miejsce danej gminy według poziomu ryzyka powodziowego w każdej jego 
Tab. 6. Klasyfikacja gmin województwa łódzkiego ze względu na syntetyczny poziom ryzyka powodziowego według autorskiej metodologii

Table 6. Classification of municipalities in Łódź province based on the total level of flood risk according to the author's methodology

\begin{tabular}{|r|l|c|}
\hline $\begin{array}{c}\text { Lp./ } \\
\text { No }\end{array}$ & \multicolumn{1}{|c|}{ Gmina/Community } & $\begin{array}{c}\text { Liczba punktów ogółem uzyskana we wszystkich } \\
\text { rankingach poziomu ryzyka powodziowego/ } \\
\text { Total number of points obtained in all } \\
\text { the rankings of levels of flood risk }\end{array}$ \\
\hline 1 & Łowicz & 18 \\
\hline 1 & Tomaszów Mazowiecki (miasto/city) & 18 \\
\hline 3 & Kutno & 23 \\
\hline 4 & Działoszyn & 24 \\
\hline 5 & Uniejów & 26 \\
\hline 6 & Poddębice & 33 \\
\hline 7 & Gidle & 35 \\
\hline 8 & Inowłódz & 37 \\
\hline 9 & Radomsko & 38 \\
\hline 10 & Sieradz (miasto/city) & 40 \\
\hline 11 & Żytno & 42 \\
\hline 12 & Burzenin & 43 \\
\hline 12 & Tomaszów Mazowiecki (gmina wiejsk/rural municipality) & 43 \\
\hline 14 & Warta & 48 \\
\hline 15 & Pęczniew & 51 \\
\hline 16 & Sulejów & 52 \\
\hline 16 & Zapolice & 52 \\
\hline 16 & Sieradz (gmina wiejsk/rural municipality) & 52 \\
\hline 19 & Ładzice & 54 \\
\hline 20 & Rozprza & 57 \\
\hline 21 & Czarnocin & \\
\hline
\end{tabular}

Źródto: opracowanie własne.

Source: author's own work.

grupie. Pozycja gminy oznaczała liczbę punktów: im mniej, tym wyższy poziom ryzyka ogółem (Borowska-Stefańska 2015b).

Empiryczną podstawą analiz w artykule był materiał zebrany podczas badań terenowych, przeprowadzonych w latach 2011-2013. Obejmowały one:

- kwerendę w urzędach i instytucjach odpowiedzialnych za ochronę przeciwpowodziową; pozyskano dane dotyczące: zróżnicowania poziomu ryzyka powodziowego w województwie łódzkim z podziałem na gminy, zasięgu wody 100-letniej;

- inwentaryzację urbanistyczną, w trakcie której zaktualizowano dane dotyczące zagospodarowania. 
Inwentaryzację terenową przeprowadzono w latach 2012-2013 na obszarze sześciu gmin - miasta oraz gminy Tomaszów Mazowiecki, Kutna, Łowicza, Poddębic, Uniejowa, która miała na celu aktualizację podkładów. Podstawę do tych analiz stanowiła Baza Danych Obiektów Topograficznych (BDOT), która - jak stwierdzono - odzwierciedla aktualny stan zagospodarowania. Dlatego też zrezygnowano z badań szczegółowych w pozostałych gminach.

Podstawą do realizacji i wizualizacji wykorzystywanych metod badawczych stały się materiały kartograficzne oraz dane zebrane podczas kwerendy w urzędach. W wyniku współpracy z Regionalnymi Zarządami Gospodarki Wodnej w Poznaniu i Warszawie, Wojewódzkim Ośrodkiem Dokumentacji Geodezyjnej i Kartograficznej w Łodzi, Biurem Planowania Przestrzennego Województwa Łódzkiego pozyskano materiały niezbędne do wykonania inwentaryzacji. Udostępnione mapy, prezentujące zasięg wody 100-letniej oraz bieżące pokrycie i użytkowanie terenu umożliwiły za pomocą narzędzi GIS analizę zagospodarowania, identyfikację grup ryzyka powodziowego oraz jego ocenę. Występowały one zarówno w formie wektorowej, jak i rastrowej (wówczas poddano je digitalizacji, a następnie wykorzystano w pracy). Zebrany materiał terenowy, w szczególności w drodze inwentaryzacji urbanistycznej, należy ocenić jako wysoce wiarygodny.

Bardzo cennym materiałem źródłowym wykorzystanym w pracy było oprogramowanie udostępniane użytkownikom na zasadach open source. W programie Geospatial Modelling Environment dokonano podziału terenu zagrożonego powodzią w badanych gminach na heksagony, co pozwoliło uniknąć błędu oraz przyspieszyło prowadzenie analiz.

W opinii autorki wykorzystany w artykule materiał źródłowy jest właściwy oraz wystarczający do realizacji założonych celów.

\section{Wyniki i dyskusja}

W wyniku dokonanych obliczeń wskazano, że najwyższy poziom ryzyka powodziowego jest w Łowiczu oraz Tomaszowie Mazowieckim (ryc. 3).

Stwierdzono, że na obszarze Łowicza dno doliny Bzury jest bardzo szerokie, w szczególności w zachodniej i wschodniej części, tam też lokalizowana jest zabudowa. Centralna część rzeki w granicach administracyjnych miasta chroniona jest przed powodzią wałami. Konflikt zagospodarowania zaznacza się również na obszarze zawala, jednak autorka nie analizowała tego terenu. Miasto Tomaszów Mazowiecki to obszar, na którym do Pilicy uchodzą mniejsze rzeki, w związku z czym dno doliny w północno-wschodniej części osiąga znaczne rozmiary, ok. 1,7 km (Trzmiel 1986). Sprzyja to lokalizowaniu zabudowy (Borowska-Stefańska 2015c). 


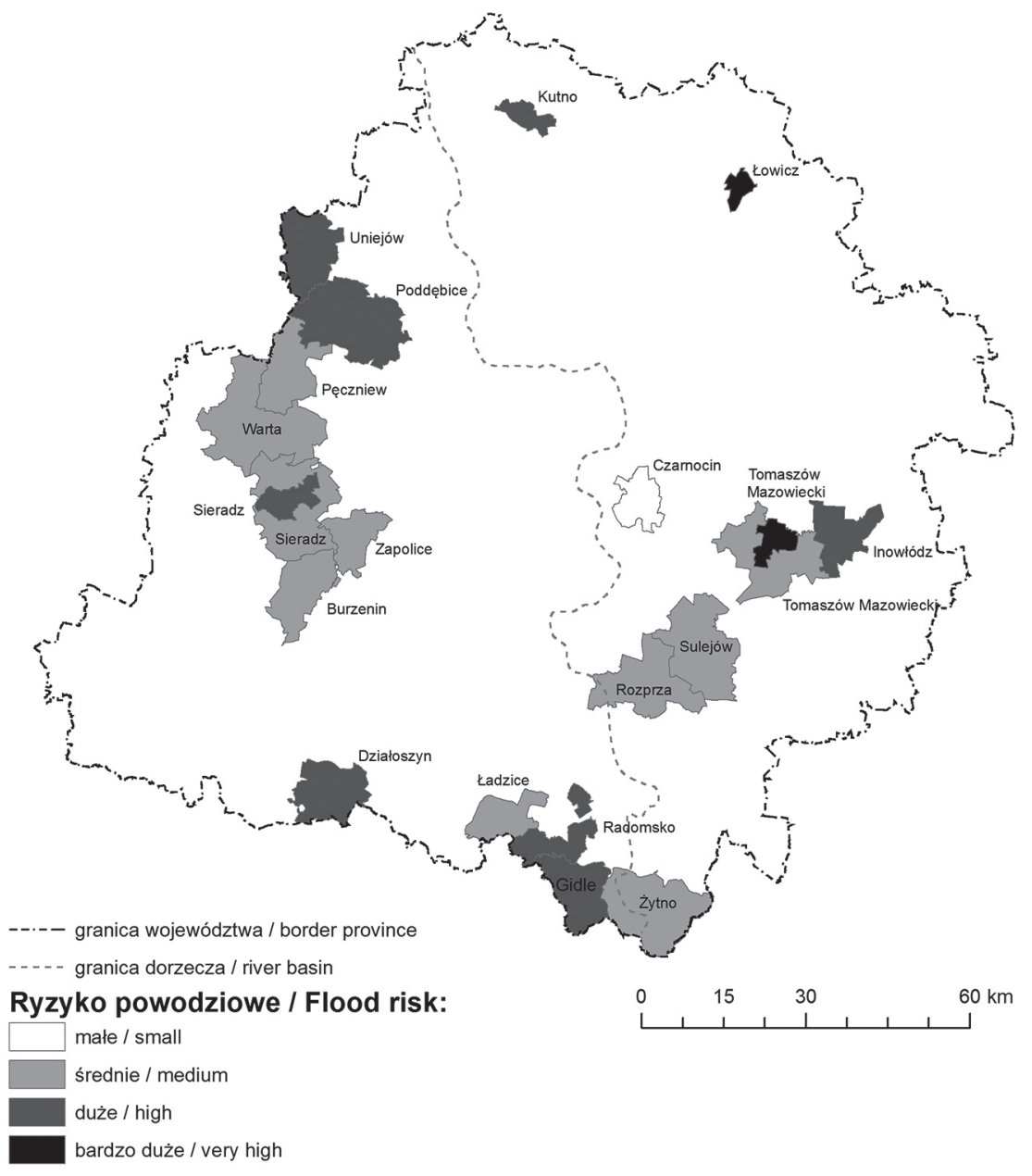

Ryc. 3. Poziom ryzyka powodziowego w wybranych gminach województwa łódzkiego według autorskiej metodologii

Fig. 3. Level of flood risk in selected communes of the Łódź province according to the author's methodology

Źródto: opracowanie własne.

Source: author's own work. 
W celu porównania metody oceny ryzyka powodziowego zastosowanej w Planie operacyjnym ochrony przed powodzią dla województwa łódzkiego (2013) z propozycją autorską zestawiono uzyskane na ich podstawie wyniki, w postaci hierarchii gmin, których różnice przedstawiono w tab. 7. Znak „,” w tabeli oznacza, że dana gmina w klasyfikacji dokonanej metodą autorską znajduje się wyżej w rankingu, zatem charakteryzuje się wyższym poziomem ryzyka powodziowego. W przypadku znaku „--” gmina znajduje się niżej w klasyfikacji przeprowadzonej

Tab. 7. Porównanie hierarchii gmin województwa łódzkiego według poziomu ryzyka powodziowego

Table 7. Comparison of Łódź province municipalities' hierarchy according to the level of flood risk

\begin{tabular}{|c|c|c|}
\hline \multicolumn{2}{|r|}{$\begin{array}{l}\text { Autorska metoda/ } \\
\text { Author's method }\end{array}$} & \multirow{2}{*}{$\begin{array}{l}\text { Miejsce gminy według autorskiej syntetycznej oceny ryzyka } \\
\text { powodziowego względem klasyfikacji z Planu operacyjnego } \\
\text { ochrony przed powodzią dla województwa łódzkiego/ } \\
\text { Rank of municipalities according to the author of the synthetic } \\
\text { flood risk assessment method in relation to the classification } \\
\text { of the Operational Flood Protection Plan for the Łódź region } \\
\text { pkt/ps }\end{array}$} \\
\hline Lp./No & gmina/community & \\
\hline 1 & Łowicz & +5 \\
\hline 1 & Tomaszów Mazowiecki (city) & 0 \\
\hline 3 & Kutno & +6 \\
\hline 4 & Działoszyn & +13 \\
\hline 5 & Uniejów & +15 \\
\hline 6 & Poddębice & +1 \\
\hline 7 & Gidle & +11 \\
\hline 8 & Inowłódz & +3 \\
\hline 9 & Radomsko & -6 \\
\hline 10 & Sieradz (city) & -6 \\
\hline 11 & Żytno & -3 \\
\hline 12 & Burzenin & +1 \\
\hline 12 & $\begin{array}{l}\text { Tomaszów Mazowiecki } \\
\text { (rural municipality) }\end{array}$ & +2 \\
\hline 14 & Warta & -12 \\
\hline 15 & Pęczniew & -5 \\
\hline 16 & Sulejów & -11 \\
\hline 16 & Zapolice & +5 \\
\hline 16 & Sieradz (rural municipality) & -4 \\
\hline 19 & Ładzice & -3 \\
\hline 20 & Rozprza & -5 \\
\hline 21 & Czarnocin & -2 \\
\hline
\end{tabular}

Źródto: opracowanie własne, 2014.

Source: author's own work, 2014. 
autorską metodą w stosunku do metody wykorzystanej w Planie operacyjnym ochrony præed powodziq... (2013), co wskazuje na niższy poziom ryzyka powodziowego ogółem. Największe rozbieżności dotyczą pięciu gmin: Uniejowa, Działoszyna, Gidli, Sulejowa i Warty (Borowska-Stefańska 2015b), (ryc. 4).

W metodzie zastosowanej przez Wydział Bezpieczeństwa i Zarządzania Kryzysowego Uniejów znalazł się dopiero na 20. miejscu; w uzasadnieniu podano, że potencjalne ryzyko jest związane przede wszystkim z możliwością awarii zapory czołowej na zbiorniku Jeziorsko. Autorka wskazała natomiast, że w granicach wody 100-letniej gminy Uniejów istnieją termy z restauracjami, pływalnią otwartą kompleksu termalno-basenowego, zespołem boisk do piłki nożnej, siatkówki, piłki plażowej, kortów tenisowych, plażą miejską oraz kąpieliskiem strzeżonym, Instytutem Zdrowia Człowieka, Kasztelem rycerskim. Obiekty te generują przede wszystkim potencjalne straty materialne, a także niebezpieczeństwo dla ludzi. W granicach terenów szczególnego zagrożenia powodzią w gminie Uniejów zidentyfikowano łącznie ponad 0,6 ha obiektów o znaczeniu społecznym. Całkowita potencjalna wielkość strat, przeliczona na podstawie ww. metodologii, wynosi 19588,42 tys. zł. W związku z tym, że zabudowa występuje przede wszystkim na obszarze miasta, to właśnie tam straty w przypadku nadejścia powodzi mogą być największe. Ponadto cały omawiany teren to obszar Natura 2000. W wyniku szczegółowej analizy aktualnego zagospodarowania Uniejów znalazł się na 5. miejscu w propozycji autorskiej. Brak uwzględnienia strat niematerialnych, w tym przypadku negatywnego oddziaływania powodzi na środowisko przyrodnicze, doprowadziło do zaniżenia pozycji Uniejowa przy ocenie ryzyka w metodzie stworzonej w Urzędzie Wojewódzkim.

W Działoszynie autorka zinwentaryzowała w granicach wody 100-letniej zabudowę mieszkalną jednorodzinną, oczyszczalnię ścieków, stację paliw. Ponadto $40 \%$ tego terenu (283 ha) zajmują Załęczański Park krajobrazowy oraz obszar Natura 2000, które w metodologii zaproponowanej przez Wydział Bezpieczeństwa i Zarządzania Kryzysowego nie zostały uwzględnione. Dlatego też syntetyczny poziom ryzyka powodziowego został w niej zaniżony.

W gminie Gidle na obszarze zagrożonym powodziami znajduje się zabudowa mieszkalna jednorodzinna, szpital powiatowy, przepompownia oraz Kościół pw. NMP Bolesnej-Sanktuarium, nie wszystkie te elementy zostały uwzględnione w Planie operacyjnym ochrony przed powodzią, dlatego też gmina ta znalazła się dopiero na 18. miejscu, natomiast w metodologii autorskiej na siódmym.

Duże rozbieżności w klasyfikacjach dotyczą również miasta i gminy Warta, która uzyskała najwyższy poziom ryzyka w metodologii Wydziału Bezpieczeństwa i Zarządzania Kryzysowego. Wskazano, że na obszarze zalewowym obejmującym 27 km² mieszka ponad 1500 osób, znajduje się szereg zakładów pracy, obiektów użyteczności publicznej, dróg oraz dwa cmentarze. W tym przypadku uwzględniono 


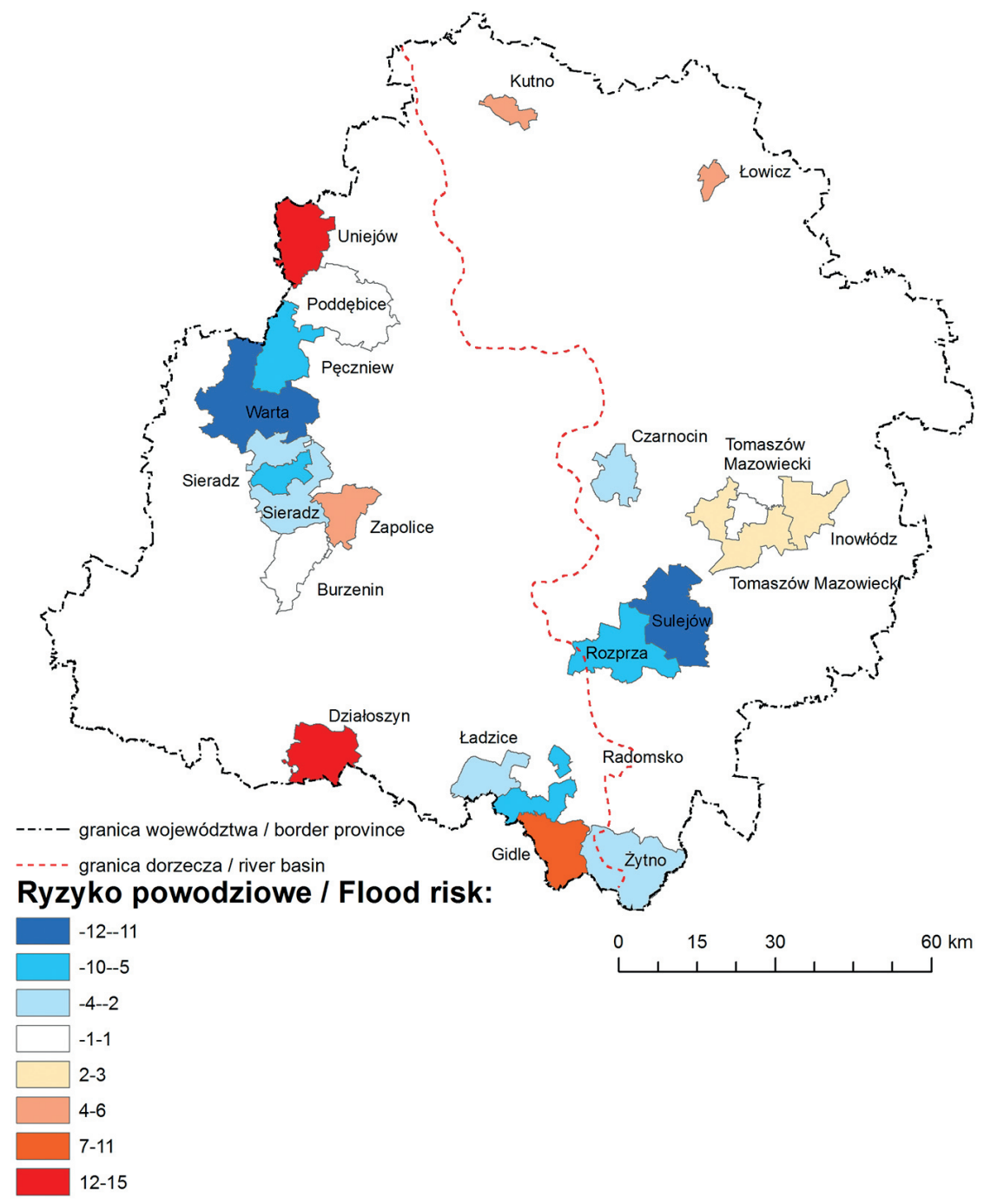

Ryc. 4. Porównanie hierarchii gmin województwa łódzkiego według poziomu ryzyka powodziowego

Fig. 4. Comparison of Łódź province municipalities' hierarchy according to the level of flood risk

Źródto: opracowanie własne, 2014.

Source: author's own work, 2014. 


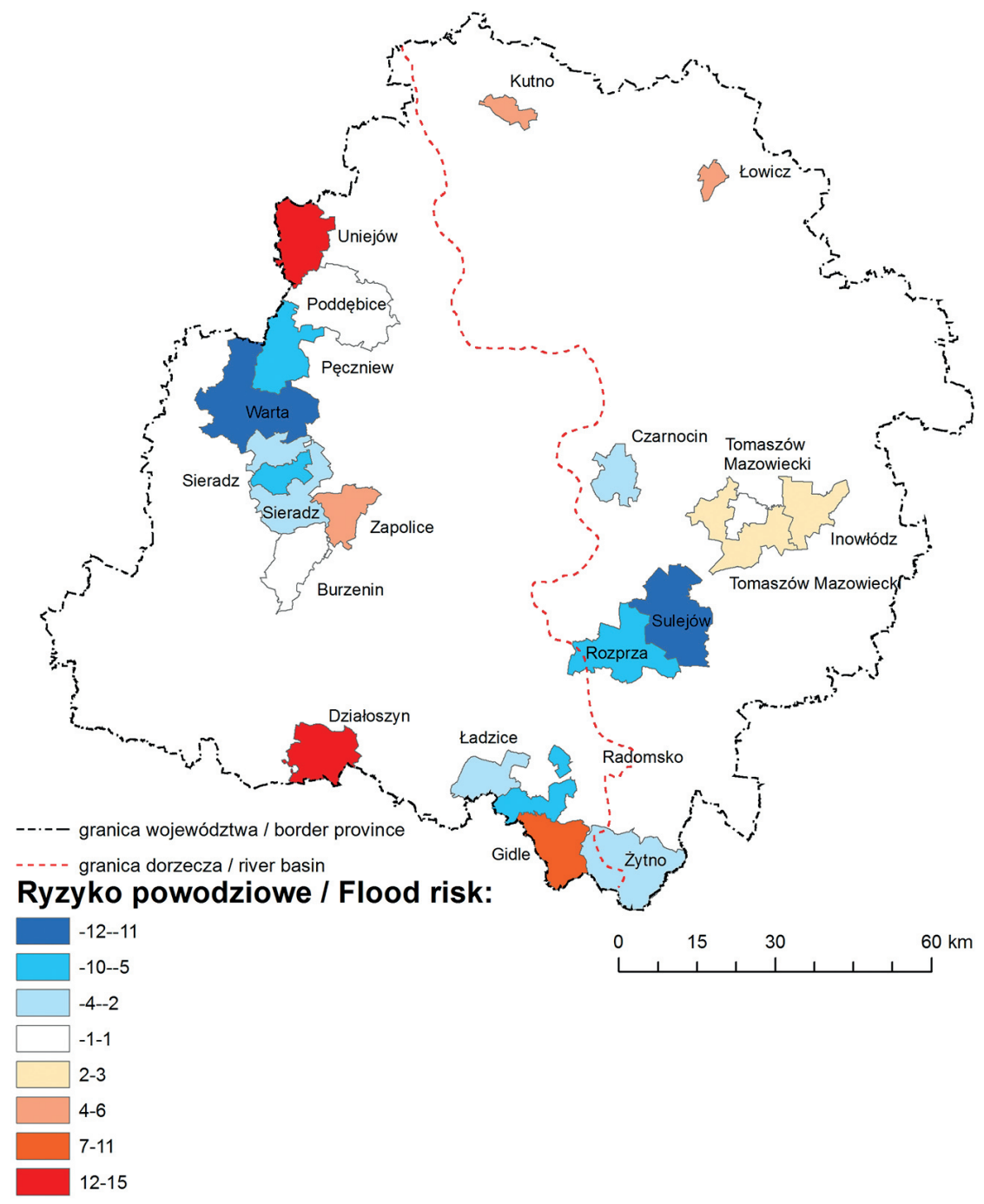

Ryc. 4. Porównanie hierarchii gmin województwa łódzkiego według poziomu ryzyka powodziowego

Fig. 4. Comparison of Łódź province municipalities' hierarchy according to the level of flood risk

Źródto: opracowanie własne, 2014.

Source: author's own work, 2014. 
nie tylko obszar wody 100-letniej, ale również tereny potencjalnego zagrożenia, które jednak w okresie, gdy badania te były przeprowadzane, nie zostały wyznaczone przez Regionalny Zarząd Gospodarki Wodnej w Poznaniu. Wskazuje to na problem niedokładnego sprecyzowania pojęcia terenu zagrożonego powodziami w ankiecie rozesłanej do gmin, które w wyniku tego różnie go interpretowały. Na podstawie badań autorki stwierdzono, że teren tzw. wody 100-letniej w granicach gminy zajmuje powierzchnię ponad 1919 ha, z czego 99,95\% to tereny wolne od zabudowy (gdyż obszar ten jest w większości obwałowany - zabudowa na obszarze międzywala nie powstaje). Wskaźnik poziomej intensywności zabudowy wynosi $0,02 \%$, natomiast wykorzystania powierzchni $0,03 \%$. Na omawianym obszarze największą powierzchnię zajmują tereny: wód - 65\% (zbiornik Jeziorsko), leśne - 19\%, oraz rolne $-16 \%$. $Z$ analizy wykluczono tereny położone poza wałami, na których znajduje się zabudowa. Cały badany obszar jest ponadto niezwykle cenny przyrodniczo (rezerwat Jeziorsko oraz obszar Natura 2000).

W metodologii zastosowanej w Planie operacyjnym ochrony præed powodziq dla wojewódঞtwa tódækiego (2013) również Sulejów uzyskał duży poziom ryzyka, co związane jest z wypłycaniem rzeki Pilicy na odcinku miasta oraz degradacją wałów przeciwpowodziowych (Ocena zagro:̇enia... 2012). Metoda autorska opierała się natomiast jedynie o analizę aktualnego stanu zagospodarowania terenów tzw. wody 100-letniej. W Sulejowie wskaźnik poziomej intensywności zagospodarowania na terenie szczególnego zagrożenia powodzią wynosi 0,7\%, wskaźnik wykorzystania powierzchni $0,8 \%$. Zdecydowanie największy udział na analizowanym obszarze mają tereny wolne od zabudowy $(99,2 \%)$, z czego $40 \%$ to tereny rolne, na tereny zaś zieleni i wód przypada po $30 \%$. W grupie terenów zabudowanych przeważają tereny usługowe i mieszkaniowe. Do terenów usługowych na tym obszarze zaliczono: port jachtowy, ośrodek wczasowo-kolonijny oraz Międzynarodowy Ośrodek Integracji Młodzieży Polskiej (Borowska-Stefańska 2015b).

Najmniejsze różnice w klasyfikacji gmin według syntetycznego poziomu ryzyka powodziowego dotyczą Tomaszowa Mazowieckiego, Poddębic, Burzenina oraz Czarnocina.

Dodatkowo analizie poddano syntetyczny poziom ryzyka powodziowego uzyskany na podstawie badań autorki, metodyki zastosowanej w Planie operacyjnym ochrony przed powodzią dla województwa łódzkiego (2013) i Planach zarządzania ryzykiem powodziowym (2015). We wszystkich metodach wysoki poziom ryzyka uzyskał m.in. Tomaszów Mazowiecki (miasto) oraz Łowicz (ryc. 5).

Wyniki uzyskane w planach zarządzania ryzykiem powodziowym (PZRP) i metodologii zastosowanej przez Wydział Bezpieczeństwa i Zarządzania Kryzysowego pokrywają się, w szczególności w przypadku gmin, w których istnieją wały przeciwpowodziowe, np. w Warcie. Jest to związane z obszarem, który podlegał analizie. W PZRP uwzględniono również tereny położone za wałami, które zostały 


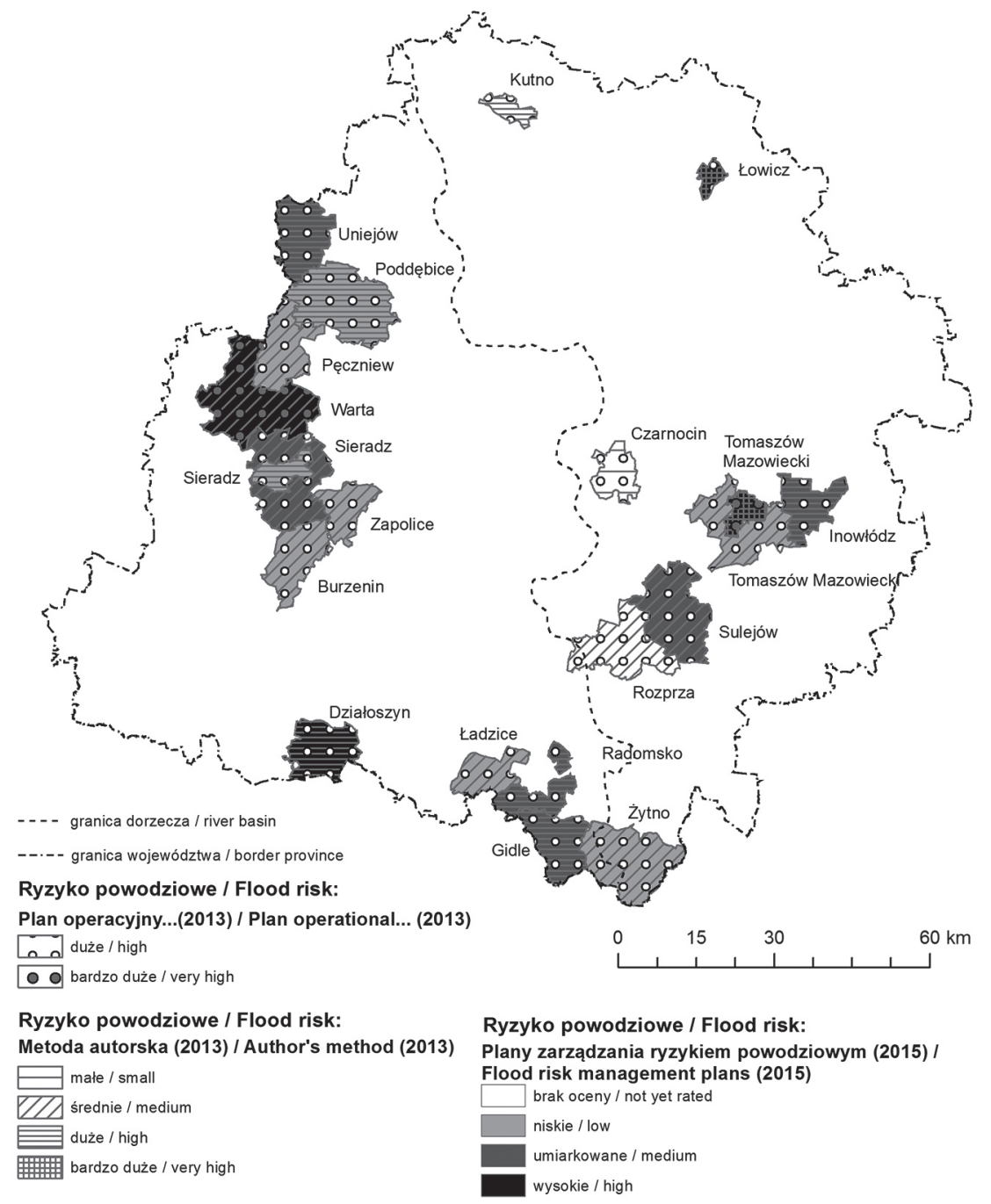

Ryc. 5. Porównanie poziomu ryzyka powodziowego według różnych metodologii Fig 5. Comparison of the level of flood risk according to different methodologies

Źródto: opracowanie własne, 2015.

Source: author's own work, 2015. 
wskazane na mapach zagrożenia powodziowego. Niestety dokumenty krajowe nie uwzględniają jeszcze analizy ryzyka we wszystkich gminach. W przypadku badanego obszaru wciąż brakuje oceny dla: Czarnocina, Kutna i Rozprzy, oraz dla mniejszych rzek, tj. Czarnej i Piasecznicy w Tomaszowie Mazowieckim.

\section{Wnioski}

Zarówno metoda wykorzystana w Planie operacyjnym ochrony przed powodziq, planach zarządzania ryzykiem powodziowym, jak i zaproponowana przez autorkę dotyczą oceny poziomu ryzyka powodziowego. Wyniki uzyskane na ich podstawie znacząco się jednak różnią, co jest związane z odmiennym podejściem do tego zagadnienia.

Metodologia zaproponowana przez autorkę opierała się tylko na analizie terenów wody 100-letniej w wybranych gminach, co jest zgodne z obecnie obowiązującymi przepisami, jednak nie odpowiada uwarunkowaniom przyrodniczym szerokich den dolinnych środkowej Polski. W dwóch pozostałych dokumentach w analizie ryzyka powodziowego wzięto pod uwagę również tereny potencjalnego zagrożenia. Propozycja autorska, choć nie uwzględnia terenów położonych poza wałami, to wskazuje na poziom ryzyka na terenach szczególnego zagrożenia, na których zgodniez art. 881 ustawy Prawo wodne z 18 lipca 2001 r. - w ogóle obowiązuje zakaz zabudowy. Ma to bardzo istotne znaczenie w prowadzeniu polityki w zakresie ochrony przeciwpowodziowej, gdyż zupełnie inne są obostrzenia dla terenów szczególnego, a inne dla potencjalnego, zagrożenia powodzią.

W propozycji autorskiej analizie poddano zagospodarowanie poprzez uwzględnienie powierzchni zajmowanej przez obiekty i tereny zaklasyfikowane do czterech wyodrębnionych grup ryzyka. Plany zarządzania ryzykiem powodziowym również uwzględniają podział na cztery kategorie, jednak pod uwagę wzięto w nich (poza wyceną strat materialnych) liczbę budynków, a nie ich powierzchnię, co zdaniem autorki nie do końca odzwierciedla poziom ryzyka powodziowego.

Na podstawie autorskiej metody możliwe jest zróżnicowanie poziomu ryzyka powodziowego na obszarze wody 100-letniej danej gminy, zarówno w każdej grupie obiektów, jak i w ujęciu syntetycznym. Ponadto na tej podstawie dokonano również hierarchii gmin ze względu na jego poziom, co znacząco ułatwia prowadzenie odpowiedniej polityki w zakresie ochrony przeciwpowodziowej.

Wypracowana metoda pozwala w granicach terenów narażonych na możliwość wystąpienia powodzi, na właściwe wyznaczenie miejsc szczególnie narażonych na negatywne konsekwencje w przypadku nadejścia powodzi. Może ona mieć istotne znaczenie dla regionów, na których powodzie nie generują ogromnych szkód i nie ma dokładnych danych o ich skutkach, w ujęciu historycznym. Na podstawie analizy bieżącego zagospodarowania można wnioskować o poziomie ryzyka. W wojewódz- 
twie łódzkim dotyczy to w szczególności terenów zalewowych mniejszych rzek, tj. Luciąży, Ochni, Czarnej, Piasecznicy, dla których nie opracowano map zagrożenia i ryzyka powodziowego.

\section{Literatura}

Barszcz M., Theobald S., Rötz A., 2013, Metodyka planu sarzqdzania ryzykiem powodziowym dla «lewni Fuldy w Niemczech, Gospodarka Wodna, 1, 21-24.

Bogdańska-Warmuz R., Grela J., Konieczny R., Siudak M., 2000, Systemy ostrzeżeń powodziowych, [w:] M. Maciejewski (red.), Model kompleksowej ochrony præed powodziq w obs:arze dor:ecza górnej Wisty na przykładzie wojewód:twa matopolskiego, IMGW, Kraków [CD-ROM].

Borowska-Stefańska M., 2014, Ocena ryzyka powodziowego jako element wdrażania Dyrektywy Powodziowej-przyktad Uniejowa, Problemy Rozwoju Miast, Kwartalnik Naukowy Instytutu Rozwoju Miast, 11, 3, 5-11.

Borowska-Stefańska M., 2015a, Flood risk assessment of Łod乏 province communes, Humanities and Social Sciences, 20, 22, 9-23.

Borowska-Stefańska M., 2015b, Zagospodarowanie terenów sagrożonych powodziami w województwie tódzkim, Wydawnictwo Uniwersytetu Łódzkiego, Łódź.

Borowska-Stefańska M., 2015c, Zagospodarowanie terenów zagrożonych powodziami w wybranych miastach województwa tódzkiego, Prace Geograficzne, 140, 57-77.

Chojnacki J., 1994, Wskazniki strat powodziowych, Gospodarka Wodna, 10, 227-231.

Chojnacki J., 2000, Szacowanie strat powodziowych, [w:] M. Maciejewski (red.), Model kom-

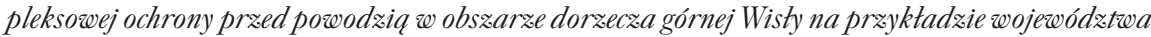
matopolskiego, IMGW, Kraków, [CD-ROM].

Crichton D., 1999, The risk triangle, [w:] J. Ingleton (red.), Natural disaster management, Tudor Rose, London, 102-103.

Crichton D., 2007, What can cities do to increase resilience?, Philosophical Transactions of the Royal Society, 365, 2731-2739.

Drożdżal E., Grabowski M., Kondziołka K., Olbracht J., Piórecki M., Radoń R., Ryłko A., 2009, Mapy ryzyka powodziowego - projekt pilotażowy w zlewni Silnicy, Gospodarka Wodna, $1,19-29$.

Dyrektywa Powodziowa, 2007, Dyrektywa 2007/60/WE Parlamentu Europejskiego i Rady z dnia 23 października 2007 r. w sprawie oceny ryzyka i zarządzania nim..

Głosińska E., 2013, Zastosowanie GIS w szacowaniu potencjalnych strat powodziowych w kontekście zagospodarowania obszarów zalewowych na przyktadzie miast województwa zachodniopomorskiego, Roczniki Geomatyki, 11, 4, 61, 25-41.

Kang J.L., Su M.D., Chang L.F., 2005, Loss functions and framework for regional flood damage estimation in residential area, Journal of Marine Science and Technology, 13, 3, 193-199. 
Konwencja w sprawie ochrony światowego dziedzictwa kulturalnego i naturalnego przyjęta w Paryżu z dnia 16 listopada 1972 r. przez Konferencję Generalną Organizacji Narodów Zjednoczonych dla Wychowania, Nauki i Kultury na jej siedemnastej sesji (Dz.U. 1976 Nr 32 poz. 190).

Kurczyński Z., 2012, Mapy zagrożenia powodziowego i mapy ryzyka powodziowego a Dyrektywa Powodziowa, Archiwum Fotogrametrii, Kartografii i Teledetekcji, 23, 209-217.

Merz B., Thieken A.H., 2004, Flood risk analysis: Concepts and challenges, Osterreichische Wasser und Abfallwirtschaft, 56, 3-4, 27-34.

Nachlik E., 2011, Wykorzystanie BDOT w ocenie ryzyka powodziowego. Problemy integracji przestrzennych informacji bazodanowych, Georeferencyjne dane przestrzenne w INSPIRE - od zbiorów do usług danych przestrzennych, VII Krakowskie Spotkania z INSPIRE, Kraków, 12-14 maja $2011 \mathrm{r}$.

Ocena zagrożenia powodziowego na obszaræe wojewódætwa tódzkiego, 2012, Wydział Bezpieczeństwa i Zarządzania Kryzysowego, Łódzki Urząd Wojewódzki w Łodzi, Łódź.

Plan operacyjny ochrony przed powodziq dla województwa tódækiego, 2013, Oddział Zarządzania Kryzysowego Wydział Bezpieczeństwa i Zarządzania Kryzysowego, Łódzki Urząd Wojewódzki, Łódź.

Rotnicka J., 2011, Gospodarka wodna w swietle uwarunkowań Unii Europejskiej, [w:] Stan gospodarki wodnej w Polsce - problematyka prawna i kompetencyjna (na przyktadzie Dolnej Wisty), Materiały z konferencji zorganizowanej przez Parlamentarny Zespół ds. Dróg Wodnych i Turystyki Wodnej 2 czerwca 2011 r. w siedzibie Senatu, Kancelaria Senatu.

Rozporządzenie Ministra Środowiska, Ministra Transportu, Budownictwa i Gospodarki Morskiej, Ministra Administracji i Cyfryzacji oraz Ministra Spraw Wewnętrznych z dnia 21 grudnia 2012 r. w sprawie opracowywania map zagrożenia powodziowego oraz map ryzyka powodziowego (Dz.U. 2013 poz. 104).

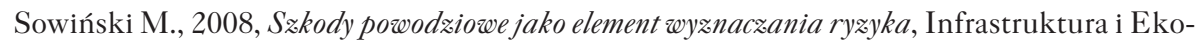
logia Terenów Wiejskich, 7, 121-130.

Szypuła M., 2001, Strefy zagro:̇enia powodziowego: metodyka określania rodæajow i sposób wyznaczania z wykorzystaniem numerycznego modelu terenu, Gospodarka Wodna, 8, 328-330.

Thieken A.H., Müller M., Kreibich H., Mer B., 2005, Flood damage and influencing factors: New insights from the August 2002 flood in Germany, Water Resources Research, 41, doi:10.1029/2005WR004177.

Trzmiel B., 1986, Szczegółowa Mapa Geologiczna Polski, arkusz Tomaszów Mazowiecki (667), 1: 50 000, Państwowy Instytut Geologiczny, Warszawa.

Ustawa z dnia 21 listopada 1996 r. o muzeach (Dz.U. 1997 Nr 5 poz. 24).

Ustawa z dnia 27 kwietnia 2001 r. Prawo ochrony środowiska (Dz.U. 2008 Nr 25 poz. 150 z późn. zm.).

Ustawa z dnia 18 lipca 2001 r. Prawo wodne (Dz.U. 2001 Nr 115 poz. 1229 z późn. zm.; Dz. U. 2012 poz. 145 z późn zm.). 
Ustawa z dnia 23 lipca 2003 r. o ochronie zabytków i opiece nad zabytkami (Dz.U 2003 Nr 162 poz. 1568 z późn. zm.).

Wołoszyn E., 2006, Oddziatywanie powodzi na Srodowisko, [w:] Vademecum ochrony przeciwpowodziowej, Gdańsk, 125-158.

http://www.kzgw.gov.pl/Dyrektywa-Powodziowa.html (27.11.2013).

http://www.powodz.gov.pl/pl/plan_view?id=1 (7.07.2015).

http://www.powodz.gov.pl/pl/plany (7.07.2015).

Marta Borowska-Stefańska

Uniwersytet Łódzki

Instytut Zagospodarowania Środowiska i Polityki Præestræennej

ul. Kopcinskiego 31, 90-142 Łód:

e-mail:borosia@op.pl 